\title{
圧縮予荷重を受けた切欠材に怙ける重裂の 発生，進展に関寸る一考察
}

\begin{abstract}
正員 阪 野 賢 治*
\end{abstract}
A Study on the Crack Initiation and Fropagation in a Precompressed Notched Specimen

by Kenji Sakano, Member

\section{Summary}

The author reported in his previous paper that almost continuous stop and go process of small crack extension was observed on the notched specimen with structural steel during unloading stage of the compression load which had been applied to a certain value at $-196^{\circ} \mathrm{C}$.

In the present paper these cracking phenomena were investigated theoretically. The state of the plastic zone spread and that of the crack initiation from the initial crack were expressed using the Dugdale model. This equation determines the crack extension length as a function of the applied stress by adopting the $\omega^{+}$(plastic zone length under tension yield stress) concept as a fracture initiation criterion. Through the judgement of the stability of the state that is expressed by this equation, the relation between precompression stress and the final fracture stress was obtained. For the convenience of the practical use, approximate equations of the analytically derived equation for a crack in an infinite plate were proposed. These theoretically derived relations were compared with those obtained through experiments and showed a fair agreement with each other.

\section{1 緒震}

構造物を製作する過程で, 鋼材が受ける種々の予ひず みが構造物の性能に及ぼす影響あるいは圧力容器に対し てなされる耐圧試験の有効性を検討するために，切欠試 験片が予荷重を受けた場合の破壊特性に関して多くの研 究がなされている。

木原ら 1 は, 大形引張試験片を用いた実験により, 室 温での引張予荷重が低温域における脆性破壞を防止する らえで有効なことを示した。このいわゆる予荷重効果の 機構の説明および定量的評価は, 予荷重の影響を塑性変 形への残留応力の影響としてとらえる酒井ら ${ }^{2)}$ にるる予 荷重 COD の切り捨て法, および越賀)による $\omega^{+}$(越 賀は $\rho^{+}$の記号を用いている）クライテリオンによって なされている。

一方, 圧縮予荷重の影響については Mylonas ら), Turner ${ }^{5)}$ が検討して括り, 压縮予荷重は破壊強度を低 下させる傾向にあることを報告している。これらの報告 に打いては, 圧縮予荷重による破壊強度低下の原因は, 主として圧縮ひずみによる勒性劣化であるとしている。 これは，圧縮ひずみがかなり大きいものであることお

\footnotetext{
* 石川島播磨重工業(株)技術研究所
}

よび使用した鋼材の特性から，残留応力の影響よりも勤 性劣化の影響が大きく現われたことによるすのであろう。

ところで, 著者は， $-196^{\circ} \mathrm{C}$ における軟鋼のようにき わめて靯性の低い材料からなる切欠試験片に, ある一定 值以上の圧縮予荷重を作用させると，予荷重を除荷する 途中で亀裂が発生し, 発生した亀裂は除荷の進行に伴い 安定して成長することを実験で確認し報告しだ)。また， この亀裂 (以後, 圧縮予荷重亀裂と呼ぶ) の発生は, 残 留応力の影響として説明できることも示した。

本報告では, 圧縮予荷重による残留応力に着目して圧 縮予荷重亀裂の発生, 進展現象を理論的に検討する。破

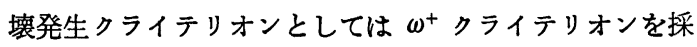
用し, 塑性变形および亀裂の発生, 進展への残留応力の 影響は Dugdal モデル7を用いて評価する。またこう して得られる圧縮予荷重亀裂が発生するときの外力（龟 裂発生応力), 亀裂の進展長ならびに試験片が全体的な 破断に至るときの外力（破断応力）の理論値が妥当であ ることを実験で確認する。

\section{2 理 論 的 検 討}

\section{1 無限平板中の単一苗裂からの破壊特性}

$\mathrm{X}$ 一 $\mathrm{Y}$ 平面の $\mathrm{X}$ 軸上に 1 個の亀裂があり, 一様な $\mathrm{Y}$ 方 
向の圧縮荷重を負荷・除荷したのち, 引き続いて引張荷 重を負荷する場合を考える。匡縮予荷重が作用した場合 でも，亀裂面が接触し荷重を受けもつことはないものと する。材料は均質, 等方性であり, しかも完全弾塑性体と する。また, 試験中は温度が一定であり, 勒性, 降伏応 力などは変化しないものとする。このような場合につい て, 脆性破壞発生条件として $\omega^{+}$クライテリオンを採用 し, 亀裂発生応力, 亀裂の進展長掞よび破断応力につい て検討する。

\section{（1）亀裂発生応力}

単純負荷の場合, 外力 $\sigma$ 之塑性域の長さ $\omega$ の関係は, Dugdal モデルにより次式で与えられる。

$$
a_{0} /\left(a_{0}+\omega\right)=\cos \left(\pi \sigma / 2 \sigma_{Y}\right)
$$

ここで, $a_{0}$ : 初期の亀裂長さ, $\sigma_{Y}:$ 材料の降伏応力

$\sigma_{P}$ なる予荷重を受けたのち， $\sigma_{P}$ よりも小さい逆向き の荷重を受ける場合の $\omega$ は, 予荷重を受けた状態を基準 に考えれば亀裂先端部の降伏した部分が逆方向に降伏す るためにはその部分の応力は $2 \sigma_{Y}$ 変化する必要があり， 次式で与えられる。

$$
a_{0} /\left(a_{0}+\omega\right)=\cos \left\{\pi\left(\sigma-\sigma_{P}\right) / 4 \sigma_{Y}\right\}
$$

しかし, 逆方向の荷重の大きさが予荷重の大きさ以上と なれば，予荷重を受けたことの影響はなくなり，外力と 塑性域の長さの関係は（1）式で与えられる。

したがって，圧縮予荷重 $\sigma_{P}$ の除荷および引張負荷の 途中で $\omega$ が $\omega_{c}^{+}$になれば破壊（亀裂）を発生するとし てそのときの外力 $\sigma_{I}$ を求めれば次のようになる。

$$
\left.\begin{array}{ll}
\sigma_{I}=\sigma_{F 0} & \left(\left|\sigma_{P}\right|<\sigma_{F 0}\right) \\
\sigma_{I}=2 \sigma_{F 0}+\sigma_{P} & \left(\left|\sigma_{P}\right| \geq \sigma_{F 0}\right)
\end{array}\right\}
$$

ここで, $\sigma_{F 0}$ : 予荷重を受けない場合の破壊発生応力 亀裂発生応力 $\sigma_{I}$ は, $\left|\sigma_{P}\right|$ が $\sigma_{F 0}$ よりも小さければ予 荷重の影響を受けないが， $\left|\sigma_{P}\right|$ が $\sigma_{F 0}$ 以上となれば $\left|\sigma_{P}\right|$ の増加量たけ減少することを表わしている。

\section{（2）亀裂進展長}

圧縮予荷重を除荷する段階あるいはそれに引続く引張 負荷段階において亀裂が発生し，その長さが $a_{0}$ から $a_{1}$ となった状態の応力分布は Fig. 1のように表わされる。

亀裂が発生した部分は降伏応力が 0 の塑性域に等しい と考えれば，この状態へ Dugdale モデルを適用するこ とができ，外力と亀裂進展長および亀裂先端の塑性域の 長さの関係を与える式が得られる。すなわち, 現在の塑 性域の先端 $a_{2}$ に拈ける特異性を 0 とする条件式として

$$
K_{\Delta \sigma}+K_{R}+K_{Y}=0
$$

が成り立つ。ここで， $K_{\Delta \sigma}$ は基準状態からの外力の変化 量 $\Delta \sigma\left(=\sigma-\sigma_{P}\right)$ による $K$ 值であり, $K_{R}$ は基準状態に おける初期亀裂先端付近の応力が $a_{0} \sim a_{2}$ 間に残留応力 として作用することによる $K$ 值であり， $K_{Y}$ は $a_{0} \sim a_{2}$ 間に作用している降伏応力による $K$ 値である。

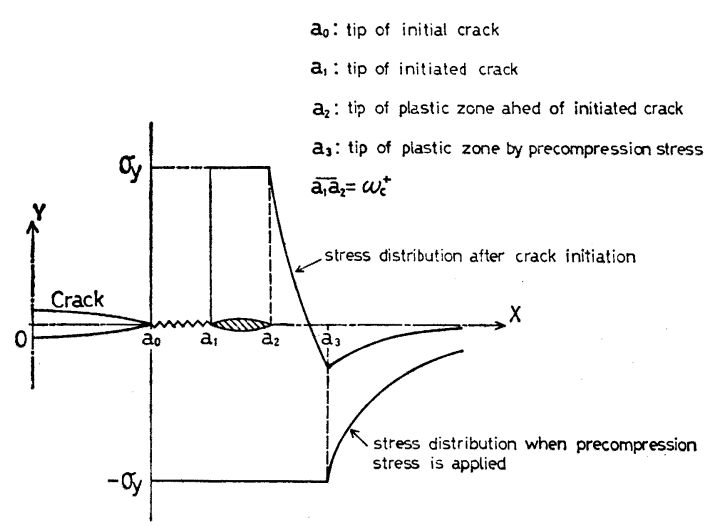

Fig. 1 Stress distribution ahead of a crack tip when precompression stress is applied and when crack is extended

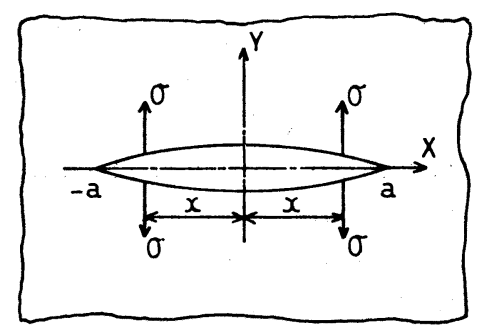

Fig. 2 Crack subjected to splitting force

Fig. 2 に示すように亀裂の中心に対して対称な位置 $\pm x$ に作用する spliting force $\sigma$ による $K$ 値は

$$
K=2 \sqrt{\frac{a}{\pi}} \frac{\sigma}{\sqrt{a^{2}-x^{2}}}
$$

で与えられる8) から，現在の塑性域の先端 $a_{2}$ が圧縮予 荷重による塑性域の先端 $a_{3}$ よりも小さい場合，（4) 式 は次のように表わされる。

$$
\begin{aligned}
& \int_{0}^{a_{2}} \frac{\Delta \sigma}{\sqrt{a_{2}^{2}-x^{2}}} d x+\int_{a_{0}}^{a_{2}} \frac{-\sigma_{Y}}{\sqrt{a_{2}^{2}-x^{2}}} d x+\int_{a_{1}}^{a_{2}} \frac{-\sigma_{Y}}{\sqrt{a_{2}^{2}-x^{2}}} d x \\
& =0
\end{aligned}
$$

すなわち

$$
\cos ^{-1}\left(a_{0} / a_{2}\right)+\cos ^{-1}\left(a_{1} / a_{2}\right)=\pi \Delta \sigma / 2 \sigma_{Y}
$$

ここで, 亀裂進展の動的影響を無視し, 亀裂は常に

$$
a_{2}-a_{1}=\omega_{c}^{+}
$$

を満たしながら連続的に進展すると考えれば，（7)式に より外力の変化量 $\Delta \sigma$ と亀裂進展長 $\Delta a\left(=a_{1}-a_{0}\right)$ の関 係を求めることができる。

$a_{2}$ が $a_{3}$ と等しくなれば, 残留応力による $K$ 值は $\Delta \sigma$ の中の圧縮予荷重量に相当する応力による $K$ 値と絶対值 が等しくなり，打ち消し合うため圧縮予荷重の影響は消 える。このため, $a_{2}$ が $a_{3}$ 以上となった状態においては, 長さ $a_{1}$ の亀裂をるつ無限平板に単純に外力 $\sigma$ を作用さ せることにより, 塑性域が $a_{2}$ まで拡大したと考えるこ 
とができ（4）式は次のようになる。

$$
\cos ^{-1}\left(a_{1} / a_{2}\right)=\pi \sigma / 2 \sigma_{Y}
$$

(3) 破断応力

（7）式あるいは（9）式で表わされる状態が安定か不 安定かを検討することにより破断応力を求める。”一定の， 外力下に打ける微小な亀裂の進展に対して塑性域の長さ $\omega^{+}\left(=a_{2}-a_{1}\right)$ が増大する傾向にあれば，亀裂はつぎつ ぎと進展しついには破断に至るであろら。一方, 逆の傾 向にあれば，微小な亀裂の進展は停止され，その状態は、 安定して存在するであろら。

(7) 式に対しては

$$
\frac{\partial \omega^{+}}{\partial a_{1}}=\frac{\omega^{+} \sqrt{a_{2}^{2}-a_{0}^{2}}-a_{0} \sqrt{a_{2}^{2}-a_{1}^{2}}}{a_{1} \sqrt{a_{2}^{2}-a_{0}^{2}}+a_{0} \sqrt{a_{2}^{2}-a_{1}^{2}}}
$$

となり，分子の各項を 2 乗して差をとることにより

$$
\frac{\omega^{+}}{a_{0}}-\frac{2 a_{0}}{a_{2}} \geq 0 \text { のとき } \frac{\partial \omega^{+}}{\partial a_{1}} \geq 0
$$

となる。一般に，圧縮予荷重亀裂が発生するような材料 に対しては $\omega_{c}^{+} / a_{0}$ は相当小さい值であると考えられる ので, 亀裂が非常に長く進展しないかざり不安定な状態 とはならないであろう。 $a_{2} か ゙ a_{3}$ となったときにちょう ぞ不安定となるような縮荷重量は

$$
\omega_{c}^{+} / a_{0}=2 \cos \left(\pi \sigma_{P} / 2 \sigma_{Y}\right)
$$

で与えられ，このときの破断応力 $\sigma_{F}$ は

$$
\sigma_{F} / 2 \sigma_{Y}=1+\sigma_{P} / \sigma_{Y}
$$

となる。（12）式で与兄られる $\left|\sigma_{P}\right|$ より大きい圧縮予荷 重に対しては, 破断は $a_{2}$ が $2 a_{0}^{2} / \omega_{c}^{+}$となったときに生 し，(7）式によりこのときの $\Delta \sigma$ は一定であることが かわる。

一方，(9）式に対しては

$$
\frac{\partial \omega^{+}}{\partial a_{1}}=\frac{\omega^{+}}{a_{1}}
$$

となり常に正であるため， $a_{2}$ が $a_{3}$ 以上となった状態で は亀裂は不安定に成長することになる。また，新しい亀 裂を発生していない状態 $\left(a_{1}=a_{0}\right)$ 飞怙いて $a_{2}$ が $a_{3}$ 以 上となったときの塑性域の長さは（1）式で表わされる ため, 亀裂発生条件を満たせば亀裂は不安定に成長する

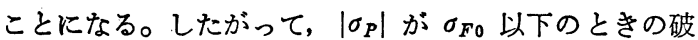
断応力は $\sigma_{F 0}$ であり, $\left|\sigma_{P}\right|$ が $\sigma_{F 0}$ より大きく（12)式 で与えられる值以下のときには破断は $a_{2}$ が $a_{3}$ となっ たときに生じることになる。

以上の検討結果をるとに， $\sigma_{F 0}$ が $0.2 \sigma_{Y}$ であるとし て, 圧縮予荷重量と亀裂進展長, 亀裂発生応力および破 断応力との関係を求め Fig. 3 亿実線で示した。压縮予 荷重の負荷・除荷だけで亀裂が発生するためには， $\sigma_{F 0}$ の 2 倍の大きさの予荷重が必要なこと，圧縮予荷重の負 荷, 除荷だけでは全体的な破断に至ることはないことな どがわかる。

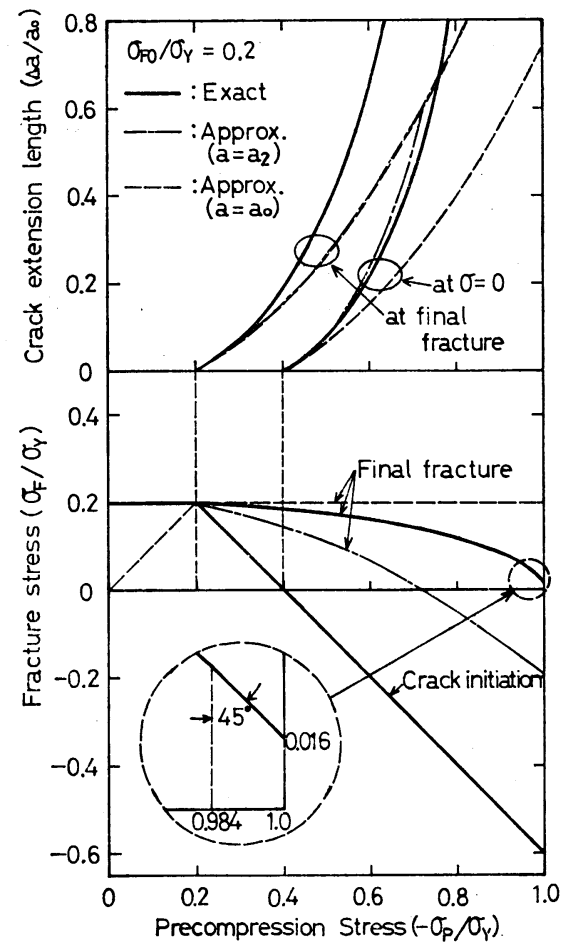

Fig. 3 Crack extension length and fracture stress in relation to precompression stress for a crack in an infinite plate

\section{2 近似式}

破壊靱性試験に用いるような試験片についてる，亀裂 面に splitting force が作用する場合の $K$ 值の計算式が あれば，(4) 式を（6）式のように具体的に表わすこと ができる。かし，K值の計算式は複雑なものが多いの で，その積分は数值計算にたよらざるを得ない場合が注 とんどである。また， splitting force が作用する場合 のK值の計算式が与えられていない試験片もある。そこ で，小規模降伏状態に対して有効な（7）式に対応する 近似式を求め，実験に用いるような試験片についての亀 裂進展長，破断応力などの評価が容易にできるようにす る。

小規模降伏状態に执いては， $K$ 值と塑性域の長さ $\omega の$ 関係は

$$
\omega=\frac{\pi}{8}\left(\frac{K}{\sigma_{Y}}\right)^{2}
$$

で与えられる。残留応力が作用する塑性域 $a_{0} \sim a_{2} お$ よ び実際の塑性域 $a_{1} \sim a_{2}$ (Fig. 1 参照) を生じるために 必要なK值をそれぞれ（15）式から求めることにより， （4）式は次のようになる。

$$
K_{\Delta \sigma}-\sigma_{Y} \sqrt{\frac{8}{\pi}}\left(\sqrt{\Delta a+\omega_{c}^{+}}+\sqrt{\omega_{c}^{+}}\right)=0
$$

（16）式から亀裂進展長を求めようとする場合必要と されるのは外力が作用した場合の $K$ 值の計算式だけであ 
り，破壊試験に用いられるような試験片についてはその 計算式が与えられている ${ }^{9}$ 。Fig. 3 の実線を求めた場合 と同じく $\sigma_{F 0}$ を $0.2 \sigma_{Y}$ として, 压縮予荷重量と亀裂進 展長拉よび破断応力の関係を (15), (16) 式から求め同 四中にあわせて示した。この結果は，(16）式中の $K_{\Delta 。}$ を計算する場合の亀裂長さとして $a_{0}$ 抢よび $a_{2}$ を用い, 破断は $a_{2}$ が $a_{3}$ となったとき生じるとしてその值を 求めたものである。予荷重が大きくなければ近似式で評 価できることがわかる。

なお，䈣密解と近似解の差は主として（15）式から計 算される圧縮予荷重量 $\sigma_{P}$ に対する塑性域の長さ $\omega(=$ $\left.a_{3}-a_{0}\right)$ の誤差から生じている。破断応力だけの精度を 上げるのであれば，破断応力を $a_{2}$ が $a_{3}$ となるときの 外力として (16) 式から求めるのではなく, 長さ $\left(a_{3}-\right.$ $\left.\omega_{c}^{+}\right)$の亀裂に長さ $\omega_{c}^{+}$の塑性域を生じさせるに必要な外 カとして（15）式から求めればよい。また，全体の精度 を上げるためには，外力と塑性域の関係をより精度のよ い近似式で推定すればょい。たと兄ば，のの代わりに有 効応力 $\sigma_{\text {eff }}$ を用いる近似

$$
\begin{aligned}
& a /(a+\omega)=\cos \left(\pi \sigma_{\text {eff }} / 2 \sigma_{Y}\right) \\
& \text { ここで, } \sigma_{\text {eff }}=K / \sqrt{\pi a}
\end{aligned}
$$

の手法を参考にして，（7）式の $\Delta \sigma を \Delta \sigma_{\text {eff }}$ で置き代 えた

$$
\cos ^{-1}\left(a_{0} / a_{2}\right)+\cos ^{-1}\left(a_{1} / a_{2}\right)=\pi \Delta \sigma_{\text {eff }} / 2 \sigma_{Y}
$$

を用いればよりよい推定ができるであるう。な特，無限 板中の単一亀裂については（18）式は啟密解と一致する。

\section{3 温度変化の影桑}

試験中に温度が変化するのであれば，それに対応して 降伏応力扰よび破壊勒性を变化させて刍裂の発生, 進展 などを検討する必要がある。温度変化の 1 例として, 室 温で圧縮荷重を負荷，除荷したのち冷却した状態で引張 荷重を負荷し破壊させる場合を考兵る。室温に拈ける破 壊勒性は十分大であり圧縮荷重を負荷，除荷するだけで は亀裂を発生することはないとする。降伏応力は温度が 低下すれば上昇する傾向にあるので，室温拉よび低温で の降伏応力をそれぞれ $\sigma_{Y}^{P} ， \sigma_{Y}^{F}$ で表わし区別すること にする。

亀裂発生応力 $\sigma_{I}$ は, $\omega_{c}^{+}$と圧縮予荷重を負荷, 除荷 したときの塑性域の長さ（それぞれ， $\omega^{-}$comp， $\omega^{+}{ }_{\text {unload }}$

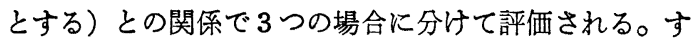
なわち，(i) $\omega_{c}^{+}$が $\omega^{-}$comp 以上のときには $\sigma_{I}$ は $\sigma_{P}$ の影響を受けず一定であり，（ii） $\omega_{c}^{+} か ゙ \omega_{\text {comp }}^{-}$より 小さく $\omega^{+}{ }_{\text {unload }}$ 以上のときには除荷開始からの外力の 変化量 $\left(\left(\sigma-\sigma_{P}\right) /\left(\sigma_{Y}^{F}+\sigma_{Y}^{P}\right)\right)$ か $\sigma_{F 0} / \sigma_{Y}^{F}$ と等しくなっ たときに亀裂を発生し，(iii） $\omega_{c}^{+} か ゙ \omega^{+}{ }_{\text {unload }}$ より小さ いときには外力 $\left(\sigma /\left(\sigma_{Y}^{F}-\sigma_{Y}^{P}\right)\right)$ が $\sigma_{F 0} / \sigma_{Y}^{F}$ と等しくな ったときに亀裂を発生する。これらを圧縮予荷重量につ
いての場合分けとし， $\sigma_{I}$ を具体的に表わせば以下のよ らになる。

$$
\left.\begin{array}{ccc}
\text { (i) } & \sigma_{I}=\sigma_{F 0} & \left(\left|\sigma_{P}\right| / \sigma_{Y}^{P} \leq \sigma_{F 0} / \sigma_{Y}^{F}\right) \\
\text { (ii) } & \sigma_{I}=\sigma_{F 0}\left(1+\sigma_{Y}^{P} / \sigma_{Y}^{F}\right)+\sigma_{P} \\
& \left(\left|\sigma_{P}\right| / 2 \sigma_{Y}^{P} \leq \sigma_{F 0} / \sigma_{Y}^{F}<\left|\sigma_{P}\right| / \sigma_{Y}^{P}\right) \\
\text { (iii) } & \sigma_{I}=\sigma_{F 0}\left(1-\sigma_{Y}^{P} / \sigma_{Y}^{F}\right) \\
& & \left(\sigma_{F 0} / \sigma_{Y}^{F}<\left|\sigma_{P}\right| / 2 \sigma_{Y}^{P}\right)
\end{array}\right\}
$$

次に，亀裂進展長怙よび破断応力であるが，（i）の 場合には，亀裂が発生すればそのまま破断に至り，(ii） の場合には, (6) 式の第 2 項, 第 3 項の $\sigma_{Y}$ をそれぞ れ $\sigma_{Y}^{P}, \sigma_{Y}^{F}$ として得られる式により評価され，(iii）の 場合も予荷重量が極端に大きくなければ（ii）の場合と 同様に評価される。ただし，(iii）の場合，発生した亀 裂に生じる塑性域の先端 $a_{2}$ が圧縮予荷重を除荷したと きに生じる塑性域の先端 $\left(a_{0}+\omega^{+}{ }_{\text {unload }}\right)$ に達するまで は，亀裂は不安定に進展する。

\section{4 切欠からの龟裂の発生, 進展}

これまでは，先端半径 $\rho を 0$ とみなせる十分鋭い亀裂 がすでにあるるのとして，そこからさらに亀裂が発生， 進展する問題を取り扱った。しかし，実験では先端半径 $\rho$ が有限な切欠材が用いられる場合もある. 切欠からの 亀裂の発生, 進展は切欠先端半径の影響を受けるである ら。そこでこれれでになされた種くの研究成果を参考 にして, 切欠からの塑性域の払がり, 亀裂の発生などを 簡単に検討しておく。

一般に, 切欠先端半径が大きくなれば，脆性破壊を発 生させるために必要な応力あるいはひずみは增大する。 切欠先端半径と脆性破壊発生応力の関係については, 塑 性域の長さおよびその中の応力に注目して，種々の検討 がなされている。しかし, 同一形状の切欠が圧縮予荷重 を受けた場合の亀裂発生応力を問題にするのであれば, 塑性域の長さそのものを計算することなく， $\sigma_{F 0}$ として 予荷重を受けない切欠からの脆性破壞発生応力の実験值 を用いることにより（3）式で評価できる。

亀裂進展長拉よび破断応力を評価するためには塑性域 の長さおよび塑性域内の応力が必要である。棈円形切欠 からの塑性域の広がりは, Fig. 4(a) のように, 主軸上 の狭い帯状領域に生じるとして，Smith ${ }^{10)}$ はモードIIIの 場合についての解析解を得ている。また, Vitek ${ }^{11)}$ は同 様の問題に対するモードI の場合の解析を行ない $x$ 軸上 の応力のつり合い式を導き数值解を求めている。Vitek の結果によれば，塑性域の長さ $\omega$ が切欠先端半径 $\rho$ 程度 となれば， $\omega$ は $\rho$ をとして評価した結果と差がなくな っている。切欠底に発生した亀裂からの塑性域の広がり は, 切欠底から直接塑性域が広がる場合よりも, 切欠先 端半径の影響を受けないであろうことは容易に想像され る。Bilby ら ${ }^{12)}$ は Fig. 4(b) 飞示すような棈円形切欠 


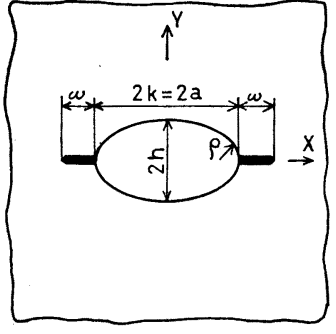

(a)

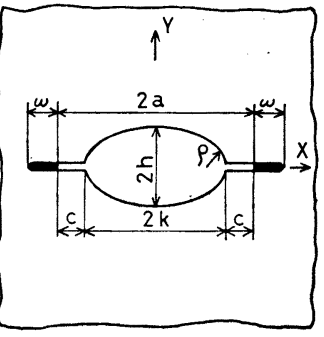

(b)
Fig. 4 Yielding from (a) notch root and (b) crack formed at notch root

底に発生した亀裂からの塑性域の広がりをモード姐の場

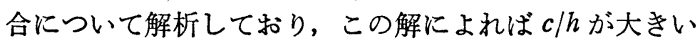
ほど塑性域の長さは長くなる傾向にあるが，c/hが 0.6 以上では楕円孔の影響を無視できることを平19)らは示し ている。

以上のことから，破壊勒性試験片に上く用いられる $0.2 \mathrm{~mm}$ 幅の切欠および本研究で用いる先端半径が 0.05 $\mathrm{mm}$ で開き角度が $30^{\circ}$ の切欠からの圧縮予荷重亀裂の 長さは, 亀裂発生初期段階を除けば, 切欠先端半径の影 響を無視して評価できるであるう。また，圧縮予荷重に よる塑性域の長さは破断応力に影響を及ぼすがその影響 は大きくなく，しかもこの塑性域の長さは亀裂進展長よ りる長いので, 圧縮予荷重による塑性域の長さる切欠先 端半径の影響を無視して評価してさしつかえないである ら。

無限平板中の切欠からの破壊発生応力 $\sigma_{F 0}$ が $0.3 \sigma_{Y}$ （同じ長さの亀裂についての $\sigma_{F 0}$ が $0.2 \sigma_{Y}$ ）であると して, 压縮予荷重量と亀裂発生応力, 破断応力就よび亀 裂進展長との関係を求め Fig. 5 亿示す。破断応力およ び亀裂進展長への切欠先端半径の影響は無視した。切欠 から亀裂が発生する応力以下では，もともと亀裂があれ ばみられる亀裂の進展は生じてないので，いったん亀裂 が発生すれば, それと同時に，亀裂は（6）式から計算 される長さまで進展することになる。

ところで，平面ひずみ状態に打ける塑性域内の荷重軸 方向応力 $\sigma_{y y}$ は 1 軸降代応力 $\sigma_{Y}$ よりも大きくなる。す べり線場理論 ${ }^{44}$ によれば， $\sigma_{y y}$ は切欠の先端半径 $\rho$, そ の開き角度 $2 \theta$ 扰よび切欠先端からの距離 $\boldsymbol{r}$ との関係で 次のように与兄られてる。

$$
\left.\begin{array}{ll}
\sigma_{y y}=\sigma_{Y}\left\{1+\ln \left(1+\frac{r}{\rho}\right)\right\} & \left(\frac{r}{\rho} \leq \exp \left(\frac{\pi}{2}-\theta\right)-1\right) \\
\sigma_{y y}=\sigma_{Y}\left(1+\frac{\pi}{2}-\theta\right) & \left(\frac{r}{\rho}>\exp \left(\frac{\pi}{2}-\theta\right)-1\right)
\end{array}\right\}
$$

これを図示したのが Fig. 6 である。なお，これは Tresca の降伏条件に対する值であり, Mises の降伏条件に

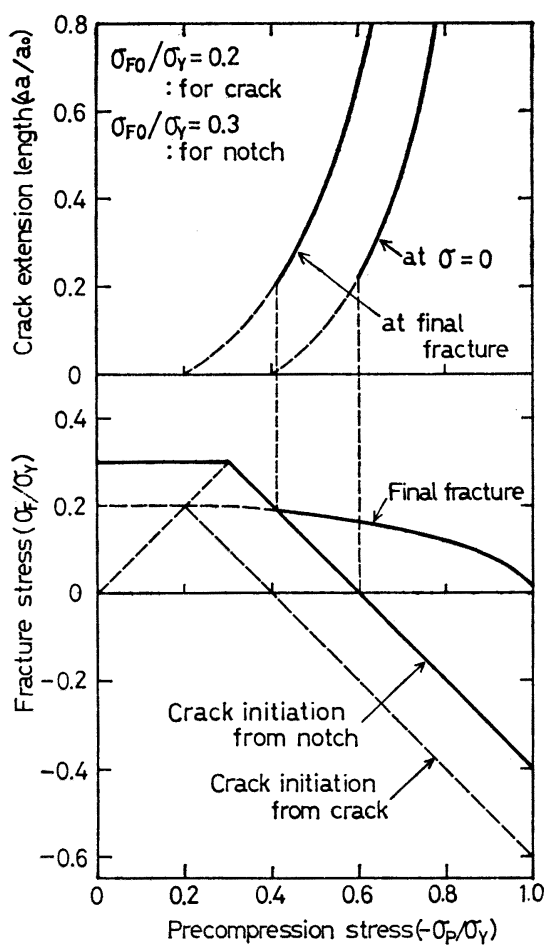

Fig. 5 Crack extension length and fracture stress in relation to precompression stress for a notch in an infinite plate

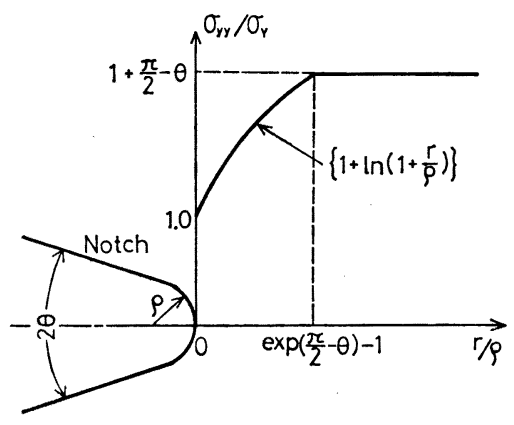

Fig. 6 Stress distribution ahead of a notch by slip line theory

対しては（20）式の $2 / \sqrt{3}$ 倍となる。この荷重軸方向 応力の降伏応力に対する比は塑性拘束係数 $p$ と呼ばれ る。压縮予荷重亀裂の発生, 進展は主として小規模降伏 状態での現象であり, しかも切欠先端近傍の現象でもあ るので，平面ひずみ状態と考学塑性拘束係数の影響を考 慮に入れる必要があろう。切欠先端半径 $\rho$ が有限の場合 $p$ は切欠先端近傍では位置の関数となるが，本研究で用 いる試験片 $\left(\rho=0.05 \mathrm{~mm}, 2 \theta=30^{\circ}\right)$ ではその範囲は局 部的 $(r \leq 2.70 \rho)$ であるので無視することにし，その影 響範囲の広い切欠の開き角に関係した $p$ の定常值 $(1+$ $\pi / 2-\theta)$ のみを考慮することにする。すなちわ，無限板 
中の単一切欠については，(6)式の第 2 , 第 3 項にそれ ぞれ $(1+\pi / 2-\theta),(1+\pi / 2)$ を掛けて得られる式を用 いる。一般の切欠試験片については（18）式に相当する 次式を用いて評価する。

$$
\begin{aligned}
& \left(1+\frac{\pi}{2}-\theta\right) \cdot \cos ^{-1}\left(\frac{a_{0}}{a_{2}}\right)+\left(1+\frac{\pi}{2}\right) \cdot \cos ^{-1}\left(\frac{a_{1}}{a_{2}}\right) \\
& =\frac{\pi \Delta \sigma_{\text {eff }}}{2 \sigma_{Y}}
\end{aligned}
$$

\section{3 実験}

\section{1 供試材, 試験片および負荷方法}

供試材は, $50 \mathrm{kgf} / \mathrm{mm}^{2}$ 級高張力鋼 (SM $50 \mathrm{C}$ ) および $80 \mathrm{kgf} / \mathrm{mm}^{2}$ 級高張力鋼 (HT 80) である。化学成分およ び機械的性質は前報6)と同じである。

試験片は, Fig.7 に示すように，標準的な切欠曲げ試 験片である。試験片の板厚は, SM $50 \mathrm{C}$ が $24 \mathrm{~mm}, \mathrm{HT}$ 80 が $27 \mathrm{~mm}$ であり, 切欠先端半径は $0.05 \mathrm{~mm}$, その 開き角度は $30^{\circ}$ である。

荷重は, 圧縮, 引張とも 4 点曲げで負荷した。

\section{2 結 果}

\section{（1）亀裂進展状況の観測}

表面ヘクラックゲージ (0.2 mm 間隔) を貼付し, 切 久部へクリップゲージを取り付けた試験片（HT 80 製） に液体窒素温度 $\left(-196^{\circ} \mathrm{C}\right)$ で圧縮曲げ荷重を負荷したの ち除荷し，さらに引張曲げ荷重を負荷し破断させた。試 験中, クラックゲージ,およびクリップゲージの出力をX ーYレコーダに記録し, 亀裂の進展状況を観測した。その 結果を Fig. 8 に示す。クラックゲージは亀裂が 0.6 $\mathrm{mm}$ 伸びたときに最初の 1 本が切れるように貼付してあ る。

Fig. 8 のクラックゲージの出力の変化から, 亀裂は除 荷の途中で発生すること，発生した亀裂は除荷の進行特 よび引張荷重の増加にともない連続的に進展することが わかる。なお，クリップゲージの出力から亀裂の進展を 確認できるのは亀裂進展量の大きい場合だけであり, 初 期の亀裂進展をクリップゲージの出力から確認すること
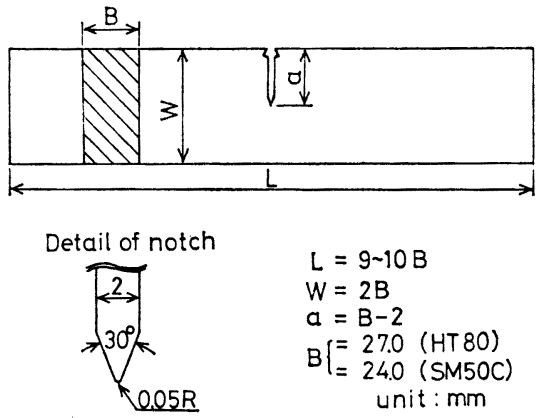

Fig. 7 Specimen geometry

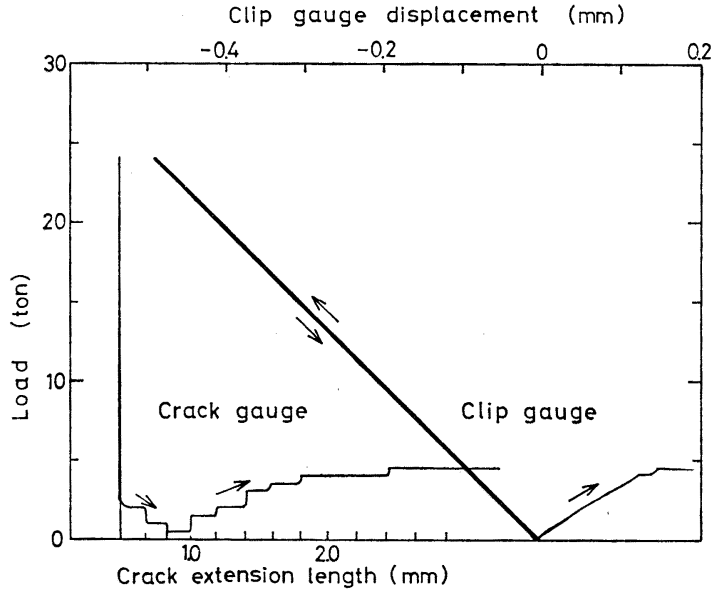

Fig. 8 A record of the outputs of a clip gauge and of a crack gauge in relation to applied load
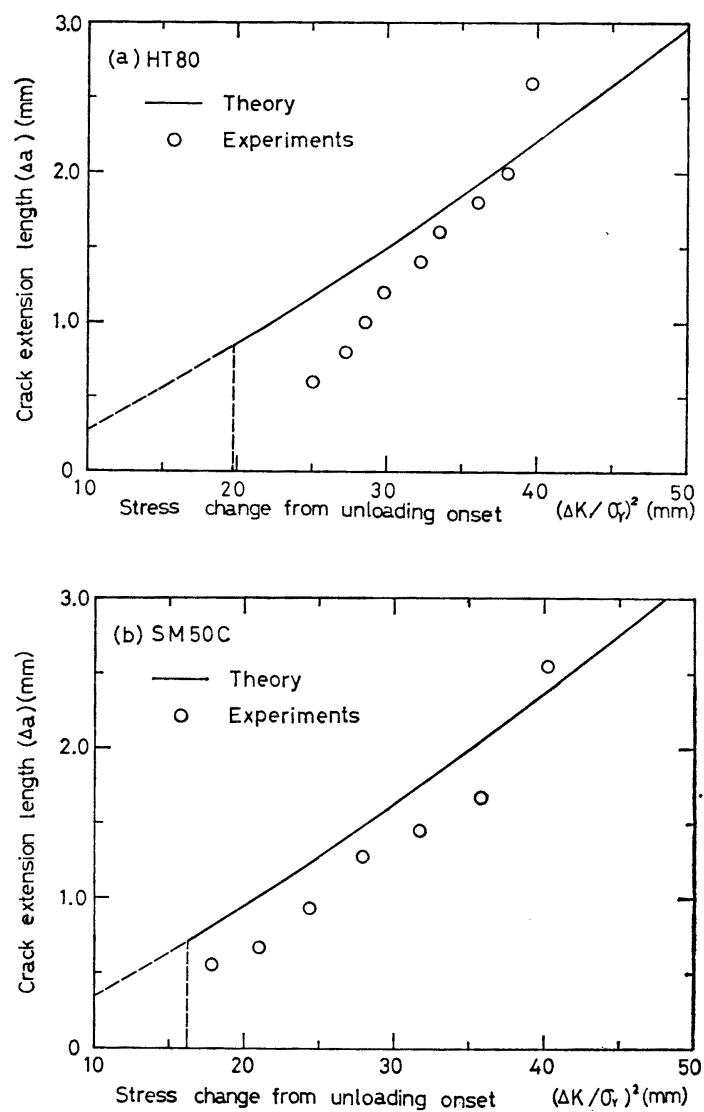

Fig. 9 Relation between stress change from unloading onset and crack extension length ((a) HT 80, (b) SM 50 C)

はでさなかった。

（2）亀裂進展長

Fig. 8 の結果を圧縮予荷重の除荷開始からの外力の变 
化量と亀裂進展長の関係で示したのが Fig. 9(a) であ る。また, SM 50C 製の試験片に種々の圧縮予荷重を負 荷, 除荷したのち亀裂の長さを計測することにより求め た同様の関係が Fig. 9(b) である。四中の曲線は（21） 式から求めた理論值である。 $\rho_{c}^{+}$は疲労亀裂を有する試 験片の破壊試験で得た $K_{\mathrm{c}}$ 值 (HT 80 が $121 \mathrm{kgf} / \mathrm{mm}^{1.5}$, SM $50 \mathrm{C}$ が $79.4 \mathrm{kgf} / \mathrm{mm}^{1.5}$ ) から算定し, HT 80 およ び SM 50 Cについてそれぞれ $0.0625 \mathrm{~mm}$ 㧊よび 0.0481 $\mathrm{mm}$ とした。また，切欠から破壊する場合の $K_{c}$ 值は HT 80 および SM 50 C についてそれぞれ $178 \mathrm{kgf} / \mathrm{mm}^{1.5}$ および $263 \mathrm{kgf} / \mathrm{mm}^{1.5}$ であった。

亀裂の発生初期および不連続な亀裂の進展を示す破断 荷重近くでは理論值と実験值に多少の誤差がみられる が, 理論式（21）により実際の亀裂進展長をほぼ推定で きるようである。

（3）亀裂発生応力扣よび破断応力

-196 $\mathrm{C}$ 飞拈いて圧縮予荷重を負荷, 除荷したのち引 張荷重を負荷し破断させる実験から求めた圧縮予荷重量 と亀裂発生応力怙よび破断応力の関係を Fig. 10(a), (b)
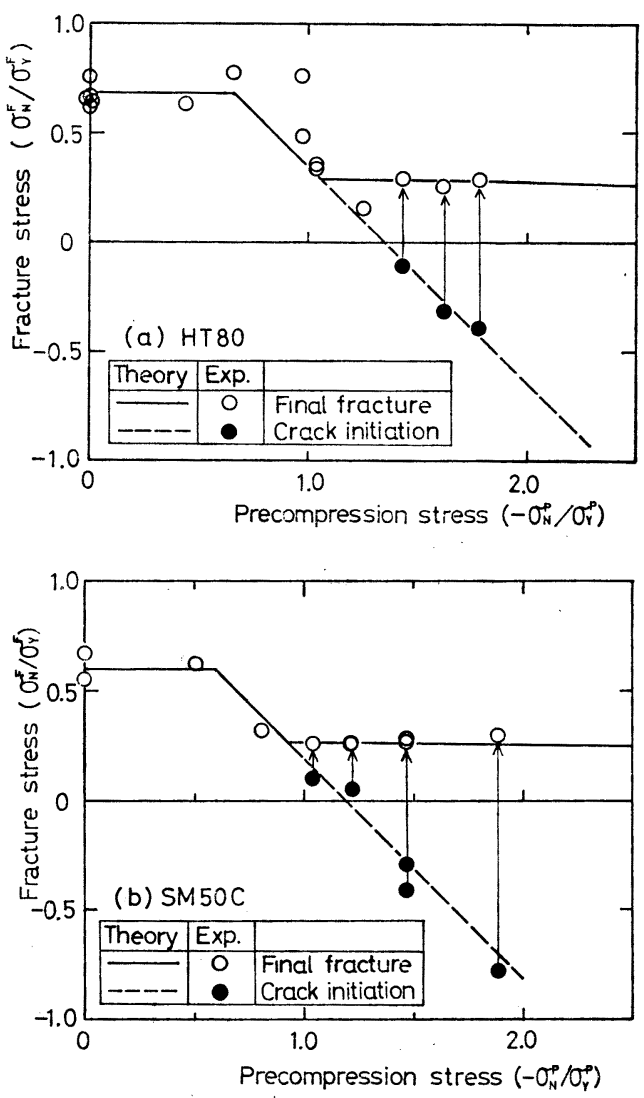

Fig. 10 Relation between precompression stress and fracture stress for the specimens precompressed and fracture at $-196^{\circ} \mathrm{C}$ ((a) HT 80, (b) SM 50 C)
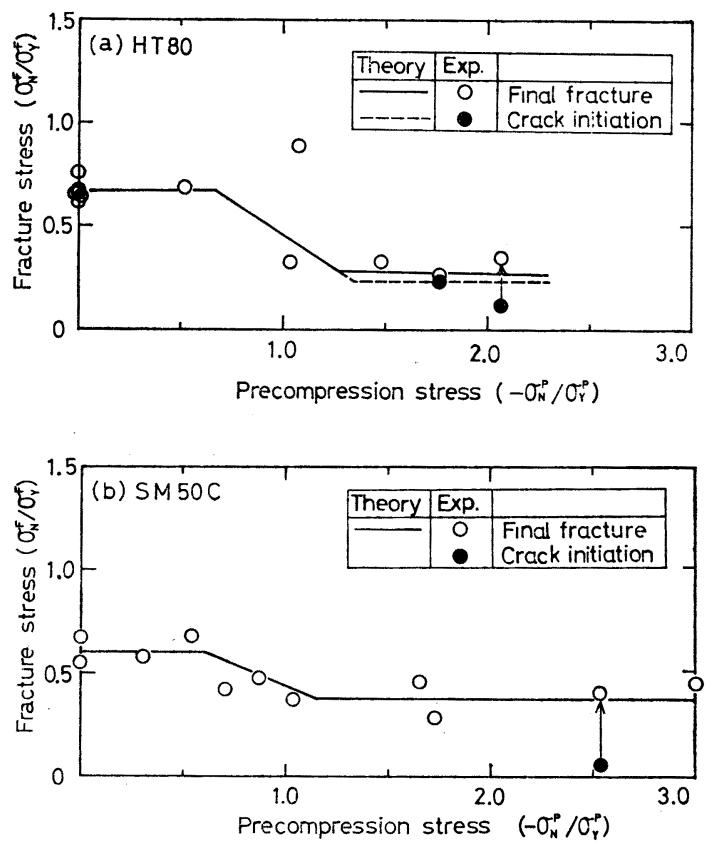

Fig. 11 Relation between precompression stress and fracture stress for the specimens precompressed at $20^{\circ} \mathrm{C}$ and fractured at $-196^{\circ} \mathrm{C}$ ((a) $\mathrm{HT} 80$, (b) $\operatorname{SM~} 50 \mathrm{C}$ )

に示す。また，室温において压縮予荷重を負荷，除荷し たのち $-196^{\circ} \mathrm{C}$ に冷却して引張荷重により破断させる実 験から求めた同様の関係を Fig. 11(a), (b) に示す。な お, 亀裂の発生は亀裂発生時に生じる “ピン”という音 から確認したものである。

この場合も実験值と理論值はかなりよい一致を示して 扣り, 理論により実際の亀裂発生応力括よび破断応力を 推定できることがわかる。なお，Fig. 11 (b) に示した， SM 50 Cで製作した試験片に室温において圧縮予荷重を 負荷, 除荷し $-196^{\circ} \mathrm{C}$ に括いて破壊させた場合について は，理論的検討によれば，すへてての予荷重範团で破壊発 生と同時に破断に至ることになる. 実験值る1つの例外 を除いて同様の傾向を示している。

ところで, 室温においてかなり大きい厌縮予荷重を受 け低温で破壊試験を実施した場合の破壊特性は，溶接継 手部に溶接線に直角に切欠がある試験片を破壊試験し た場合にみられる低応力レベルにおける亀裂の発生およ びその亀裂が停止された場合の破断応力の上昇といら現 象 ${ }^{15)}$ に類似している。溶接継手部におけるこのような破 壊特性を定量的に評価するためには，局部的な材質変化 の影響掞よび亀裂進展の動的影響を考慮に入れる必要が あろらが，本報告で示した亀裂の発生，進展および試験 片の破断を評価する手法は一つの手がかりとなるである ら。 


\section{4 結論}

压縮予荷重を受けた切欠材の破壊発生特性を論理的に 検討した。すなわち，切欠先端における塑性域の広がり および亀裂の進展の状態を Dugdale モデルで表わし， 破壊発生のクライテリオンとして $\omega^{+}$クライテリオンを 用いることにより，压縮予荷重と亀裂発生応力および亀 裂進展長の関係式を求めた。また, Dugdale モデルで 表わされた状態が安定であるか不安定であるかを検討す ることによって破断応力を求めた。こうして得られた結 果は実験結果とよい一致を示し, 理論の妥当性が確認さ れた。

本報告で用いた手法に局部的材質变化の影響および亀 裂進展の動的影響を取り入れれば, 溶接継手部にある切 欠からの低応力レベルに和ける亀裂の発生, 停止および 最終破断強度を, 定量的に評価することが可能となるで あろう。

扔わりに，本研究に対して有益なご討論，ご教示をい ただいた金沢 武東大教授をはじめ, 日本造船学会溶接研 究委員会の委員各位に深く謝意を表します。また, 研究実 施にあたって多くのご支援をいただいた，石川島播磨重 工業(株)技術研究所構造強度部の方々に感謝いたします。

\section{参考文 献}

1) H. Kihara, K. Masubuchi, K. Iida and H. Oda: Effect of Stress Relieving on Brittle Fracture Strength of Welded Steel Plate, IIW Doc. X-218-59 (1959).

2）秋田好雄, 矢田敏夫, 酒井啓一 : 鋼構造物飞発生 する脆性破壞と残留応力, 日本造船学会論文集, 第 125 号 (1969)， 227.

3）越賀房夫：予荷重が脆性破壊事故防止飞果す役割
の Dugdale 模型による機構の考察，日本造船学 会論文集, 第 127 号 (1970)，239 245.

4) C. Mylonas, D. C. Drucker and J. D. Brunton: Static Brittle Fracture Initiation at Net Stress $40 \%$ of Yield, Weld. J., Vol. 37, No. 10 (1958), $473 \mathrm{~s} \sim 479 \mathrm{~s}$.

5) C. E. Turner: A Note on Brittle Fracture Initiation in Mild Steel by Prior Compressive Pre-Strain, J. Iron. Steel Inst. 197 (1961), $131 \sim 135$.

6）阪野賢治：王縮予荷重による発生する亀裂を用い た破壊勒性評価法の研究, 日本造船学会論文集, 第 141 号 (1977)，282 289.

7) D. S. Dugdale : Yielding of Steel Sheets Containing Slits, J. Mech. Phys. of Solids, Vol. 8 (1960), 100 104.

8) G. R. Irwin : Analysis of Stresses and Strains near the End of a Crack Traversing a Plate, J. Appl. Mech. Vol. 24 (1957), 361.

9）たとえば, H. Tada, P. Paris and G. R. Irwin : The Stress Analysis of Cracks Hand Book, DEL Research Corporation, (1974).

10) E. Smith : Fracture Initiation at a Sharp Notch, Proc. Roy. Soci. London, A 299 (1967), 455 463.

11) V. Vitek : Yielding from a Crack with Finite Root-Radius Loading in Uniform Tension, J. Mech. Phys. Solids, Vol. 24 (1975), 67 76.

12) B. A. Bilby and P.T. Heald : Proc. Roy. Soci. London, A 305 (1968).

13）平修二, 田中㤵介，横幕俊典：B C S モデル解析 のいくつかの近似, 材料, 第 24 巻, 第 263 号 (1975), 25 32.

14) R. Hill : The Mathematical Theory of Plasticity, Oxford University Press, Oxford (1950).

15）たとえば, W.J. Hall, W.J. Nordell and W. H. Munse : Studies of Welding Procedure, Weld. J., Vol. 41 (1962), 505s 518s. 